\title{
Examination of Socialization Level of University Students Engaged in Sports Activities According to Their Locus of Control
}

\author{
Mehmet İnan ${ }^{1}$, Cengiz Karagözoğlu ${ }^{2}$, Fatih Dervent ${ }^{2}$, Bülent Arslantaş ${ }^{3}$ \\ ${ }^{1}$ Ataturk Faculty of Education, Marmara University, Istanbul, Turkey \\ ${ }^{2}$ School of Physical Education and Sports, Marmara University, Istanbul, Turkey \\ ${ }^{3}$ Department of Physical Education and Sports, Istanbul Technical University, Istanbul, Turkey \\ Correspondence: Fatih Dervent, School of Physical Education and Sports, Marmara University, Istanbul, Turkey
}

Received: February 2, 2015 Accepted: February 26, 2015 Online Published: March 24, 2015

doi:10.11114/jets.v3i3.662 URL: http://dx.doi.org/10.11114/jets.v3i3.662

\begin{abstract}
In this study, the university students who participate in sports have been examined in terms of their socialization relative to the participation in sport activities and the locus of control. Students are thought to be engaged in many activities in addition to their lessons during their student tenure at higher education institutions. Their participation in such activities is examined to find out whether the students take part in the mentioned activities on their own accord, or through the manipulation of others. The sample of this research consisted of students who studied at the Marmara, Istanbul Technical (ITU), and Haliç universities ( $\mathrm{n}=174)$. Data collection was based on Şahan's (2007) scale of "Role of the Sportive activities in Socialization Process of the University Students" ( $r=0.77, r=0.84)$ and Dağ's (2002) "Scale on Locus of Control" $(\alpha=.92)$. The obtained results demonstrate significant differences between the items in the socialization scales and the characteristics of locus of control of the university students. Significant differences have been detected between the items of socialization scales and university students' interest (i.e., amateur, spectator, no interest) in sports. The only significant difference in terms of gender was determined in sport and socialization skills.
\end{abstract}

Keywords: socialization, sport activities, university students, locus of control

\section{Introduction}

It might be said that young generations are not physically active enough (Vilhjalmsson \& Kristjansdottir, 2003) and participation in physical activity is still in a declining trend (Dinger, Behrens, \& Han, 2006). Hence, many governmental bodies are conducting various youth projects to promote physical activity and sports participation. There is considerable evidence on the numerous benefits of sports participation for youth. Studies showed that regular physical activity helps to develop positive effects on physical and mental health (Jewett et al., 2014; Strong et al., 2005), motivation, teamwork and self-discipline (Rees \& Sabia, 2010), reduced illegal behavior (Davis \& Menard, 2013), social and moral development (Seefeldt \& Ewing, 1997) and many other positive enhancements for youth. The effects of sport participation in school are related to the participant or school characteristics (Marsh, 1993). Personal characteristics which determine an active lifestyle have been studied by various researchers. Gender is one of the most important determinants in sport participation. Male students perceive sport participation as a reality check (Pot, Schenk, \& van Hilvoorde, 2014) and they may personally represent themselves. Conversely, female students are considered more socially-oriented and tend to participate in team events if they have a chance to choose the kind of event (Drake et al 2014). School sports participation is frequently mentioned as a social activity (Pot et al., 2014). According to Giuliano, Popp, and Knight, (2000) sport involvement is also a method of female socialization, and also provides participants small worlds of social identification (Kimball \& Freysinger, 2003) to socialize themselves by helping them to express themselves. Sport participation provides a social environment for interactions and establishing new personal relations, but just one event doesn't guarantee enough sustained participation. Jewett et al. (2014) found that different types of school sport activities enable students more regular sport participation.

Grusec and Hastings (2007) define the concept of socialization as a bidirectional process in which the individuals are supported as they are members of a group. Barbalet (2004) states that this process is deeply interrelated with the emotions. Furthermore, such statements as learning the existence of other individuals around themselves, and the fact that they as well have some rights and desires (Gün, 2006; Kiremitçi, 2007), and social competency (Çakıc1, 2010) are also observed 
to be utilized in explaining and defining the concept of socialization. University students transfer from the environment in which their families live to the environment in which their universities are located. In the socialization process they experience in this new environment, the students restructure the roles that they have brought from the past. For the students, the most beneficial outputs of this process are self-confidence and self-awareness (Howkins \& Ewens, 1999). As the university students control themselves, they also find out about the existence, rights, and desires of the others. Self-control is included in the definition of the locus of control. Bilgin (2010) defines the locus of control as follows: the step where the individuals develop quite consistent expectations in their development processes starting from childhood on such topics as which behavior could cause which results, and which results are caused by themselves and which are caused by exterior factors, and where the forces determining the positive or negative results in life are gathered as the individuals name their above-mentioned expectations as beliefs for the internal or external control sources. The concept of locus of control is based on Rotter's (1966) theory of social learning, and defines the locus of control as the expectations on whether the rewards and penalties are controlled by the individuals themselves, or some forces other than these individuals (Küçükkaragöz, Akay, \& Canbulat, 2013). Çırakoğlu and Tezer (2010) state that individuals with an external locus of control, in terms of the interpersonal relations, are generally incompetent in their social skills. And those with an external locus of control are generally more successful and socially more powerful, whereas Mueller and Thomas (2000) emphasize that the individuals with an internal locus of control have higher entrepreneurial abilities.

Sport participation is reported to be considered as a norm for university students (Kilpatrick, Hebert, \& Bartholomew, 2005) and young populations in Western countries normally participate in sports at some stage of their lives (Telama, Yang, Hirvensalo, \& Raitakari, 2006). Besides the benefits of sport participation for physical and psychological health (Koivula, 1999; Artinger \& Forrester, 2006), it is known as an agent for socialization. Sport participation does not result in social and emotional development itself, unless sport experience fosters positive experiences and minimizes negative experiences (Seefeldt \& Ewing, 1997).

According to Vilhjalmsson and Kristjansdottir (2003), males and females are influenced differently from significant others. This fact seems to explain how males and females might have different ways of socialization, and also how they might have different locus of control structures in terms of sport participation. Locus of control is also important for self-motivation to participate in sports activities. Studies present that internal motivation, which is affected by locus of control, is important for exercise participation. Internal motivation is accepted as one of the main factors for continuous participation in physical activity for health (Biddle \& Mutrie, 2008; McCready \& Long, 1985). Steptoe and Wardle (2001) found that individuals who have high internal locus of control showed more healthy behaviors than those who have less internal locus of control. Results of Parsons and Betz's (2001) study on woman varsity sport participants appeared to demonstrate a positive relationship between physical activity participation and internal locus of control.

After a review of various locus of control studies, Abusabha and Achterberg addressed locus of control as a mediator on health value and self-efficacy (Abusabha \& Achterberg, 1997). Locus of control interacts with health-related behaviors such as nutrition, regular exercise and weight control. However, Weiss and Larsen (1990) reported very little relationship between health locus of control and self-protective behavior on arts college students. Studies above have shown consistency on locus of control between male and female students, but physical activity related to socialization is more inconsistent. Socialization, physical activity participation and locus of control relationships are still an area of interest.

Such concepts in literature as socialization, theory of social learning, locus of control, and personality have oriented our interest in the socialization of university students into this field. We tried to look for answers to the 3 hypotheses below:

Hypothesis 1: What is the relationship between socialization and locus of control of the university students?

Hypothesis 2: What is the relationship between the socialization of the university students and their interest in sports?

Hypothesis 3: What is the relationship between socialization and the gender of the university students?

\section{Method}

\subsection{Research Model}

Research is based on the screening model. Karasar (2006) defines the screening model as depicting a past or existing condition as the way it is. This study is appropriate for the screening model since it analyzes the socialization of the university students according to the internal-external locus of control, and aims at collecting data on an existing condition.

\subsection{Population and Sample}

The population of this research consists of students who study at the Marmara, Istanbul Technical (ITU), and Haliç universities. The research sample is comprised of 174 students studying at the above-mentioned universities. Students in the sample group are all interested in sports. Data relating to the population and the sample are presented in Table 1. 
Table 1. Some demographic characteristics of the participants.

\begin{tabular}{llll}
\hline & & $\mathrm{n}$ & $\%$ \\
\hline \multirow{2}{*}{ Gender } & Female & 60 & 34.5 \\
& Male & 114 & 65.5 \\
\multirow{3}{*}{ Age } & $17-20$ & 30 & 17.2 \\
& $21-24$ & 136 & 78.2 \\
& $25-28$ & 6 & 3.4 \\
\multirow{2}{*}{ University } & $28+$ & 2 & 1.1 \\
& Haliç & 59 & 33.9 \\
& ITU & 46 & 26.4 \\
\hline
\end{tabular}

With a total of 174 students, $60(34.5 \%)$ female and $114(65.5 \%)$ male students have participated in this study. The majority (78.2\%) of the students in this research group are in the age group of 21-24 years (Table 1).

\subsection{Data Collection Tools}

Two data collection tools have been utilized in this study. The first one is Şahan's (2007) questionnaire of "Role of the Sportive activities in Socialization Process of the University Students" ( $r=.77 ; \mathrm{r}=.84)$. Since the researcher has called it a "questionnaire", we have also used this data collection tool by the same name. The first part of the questionnaire is composed of demographic properties. The second part includes 34 questions in the "socialization" section, and 35 questions on "sports and socialization". The questionnaire takes approximately 15-20 minutes to answer. The second data collection tool used in this research is Dağ's (2002) "Scale for Locus of Control" ( $r=.92)$. This scale is answered in the Likert format: "completely disagree" (1), "disagree" (2), "agree" (3), "notably agree" (4), and "completely agree" (5). Of all the questionnaire items, 42 items are plain, and 38 are reverse. An increase in points reflects the notion of external locus of control.

\subsection{Data Collection Process}

Data collection tools utilized in this study have been provided to the university students by the researchers at their own institutions. Students have been asked to fill in the questionnaires, and afterwards, the tools have been re-collected. The collected data have been reviewed by the researchers, and the incomplete as well as the non-filled questionnaires have been cleaned out. The data on the fully completed data collection tools have been entered into a computed statistics program.

\subsection{Data Analysis}

Infrastructures of the data collected on the evaluation tools have been prepared on the computed statistics program, and calculations have been performed as per the data. Socialization points of the university students have not been calculated separately for each item; rather, calculations have been based on the total points. On the scale for locus of control, statistical calculations have been performed based upon the students' points relating to the internal and external locus of control. The collected data have been analyzed, and presented on the related tables.

\section{Findings}

Findings of this researched established on three hypotheses are presented below.

\subsection{Hypothesis 1: What is the Relationship between Socialization and Locus of Control of the University Students?}

Three scales have been utilized in relation to this hypothesis. These are "sports and socialization", "socialization", and scales for "locus of control". Significant differences have been detected between the items in the socialization scales and the characteristics of locus of control of the university students. Insignificant items on the scales have been excluded in this section. 
Table 2. Results pertaining to the findings between the participants' sports and socialization, and their characteristics of locus of control.

\begin{tabular}{|c|c|c|}
\hline Sports and socialization scale, item no and item & $\begin{array}{l}\text { According to their } \\
\text { internal locus of } \\
\text { control } \\
\text { characteristics }\end{array}$ & $\begin{array}{l}\text { According to their } \\
\text { external locus of } \\
\text { control } \\
\text { characteristics }\end{array}$ \\
\hline
\end{tabular}

1. My personal interests and abilities are determinant in the $\mathrm{t}=-3.281 ; \quad \mathrm{sd}=172$; sports branch I'm interested in

$\mathrm{x}=4.12 ; \mathrm{p}<.001$

4. I like doing sports with individuals of any age group, gender, $\quad t=-3.199 ; \quad s d=172$; and income level

$\mathrm{x}=3.99 ; \mathrm{p}<.002$

5. In the sportive activities, I do not behave in a way that $t=-2.316 ; \quad s d=172$; conflicts my interests just so as to satisfy the others $\quad x=3.86 ; p<.022$

7. People can get to know me even better in the sportive $t=-2.300 ; \quad s d=172$; activities

$\mathrm{x}=3.63 ; \mathrm{p}<.023$

9. I feel lonely in the sportive activities in which team sports are performed

$\mathrm{t}=5.982 ; \quad \mathrm{sd}=172$;

$\mathrm{x}=3.04 ; \mathrm{p}<.000$

17. Even though the others might disaffirm me, I defend my $t=-3.704 ; \quad s d=172$; rights and tell the truth

$\mathrm{x}=4.03 ; \mathrm{p}<.000$

18. I prefer activities relating to the team sports

19. Sports contributes to the social integration among the

different societies

$\mathrm{t}=-2.523 ; \quad \mathrm{sd}=172$;

$\mathrm{x}=3.80 ; \mathrm{p}<.013$

20. I express myself more liberally in the sportive activities

21. Sports and the sportive activities enable the social integration

$\mathrm{t}=-3.143 ; \quad \mathrm{sd}=172$;

$\mathrm{x}=4.18 ; \mathrm{p}<.002$

$\mathrm{t}=-2.535 ; \quad \mathrm{sd}=172$;

$\mathrm{x}=4.00 ; \mathrm{p}<.012$

22. Could the outlaw behaviors in the sportive activities be tolerated (cursing, actions contradicting the gentlemanship)

23. I prefer having an original value structure rather than being part of a group

24. Sports contributes to the interpersonal communication

25. I easily adapt to any sportive activities and sports

26. I communicate with the others more easily in the sportive activities

$\mathrm{t}=-2.399 ; \quad \mathrm{sd}=172$;

$\mathrm{x}=4.11 ; \mathrm{p}<.018$

27. Sports training has an important role in raising socially beneficial individuals

28. Sports helps to explore the personal abilities

29. Sports contribute to the development of positive emotions towards the other people

31. I like to spend my free time with other people

32. I like to do sports with my friends

33. My family and environment is determinant in the sports branch I'm interested in

$$
\begin{array}{cc}
\mathrm{t}=-4.355 ; & \mathrm{sd}=172 \\
\mathrm{x}=4.18 ; & \mathrm{p}<.000 \\
\mathrm{t}=-2.761 ; & \mathrm{sd}=172 ; \\
\mathrm{x}=3.97 ; & \mathrm{p}<.006 \\
\mathrm{t}=-2.294 ; \quad & \mathrm{sd}=172 ; \\
\mathrm{x}=4.04 ; & \mathrm{p}<.023 \\
\mathrm{t}=-3.092 ; \quad & \mathrm{sd}=172 ; \\
\mathrm{x}=4.26 ; & \mathrm{p}<.002 \\
\mathrm{t}=-4.328 ; \quad \mathrm{dd}=172 ; \\
\mathrm{x}=4.34 ; \mathrm{p}<.000 \\
\mathrm{t}=-2.491 ; \quad \mathrm{sd}=172 ; \\
\mathrm{x}=4.17 ; \mathrm{p}<.014 \\
\mathrm{t}=-2.137 ; \quad \mathrm{sd}=172 ; \\
\mathrm{x}=3.92 ; \mathrm{p}<.034 \\
\mathrm{t}=-3.632 ; \quad \mathrm{sd}=172 ; \\
\mathrm{x}=4.26 ; \mathrm{p}<.000
\end{array}
$$$$
\mathrm{t}=6.231 ; \quad \mathrm{sd}=172
$$$$
\mathrm{x}=3.14 ; \mathrm{p}<.000
$$$$
\mathrm{t}=2.982 ; \quad \mathrm{sd}=172
$$$$
\mathrm{x}=3.44 ; \mathrm{p}<.003
$$

$\mathrm{t}=4.048 ; \quad \mathrm{sd}=172$ $\mathrm{x}=3.35 ; \mathrm{p}<.000$

H1. a. 1. The following deductions could be made for the university students with structures relating to an internal locus of control: "their personal interests and abilities are determinant in the sports branch they are interested in", "they like doing sports with individuals of any age group, gender, and income level", "they do not behave in a way that conflicts their 
interests just so as to satisfy the others", "people can get to know them even better through the sportive activities", "they feel lonely in the team sports", "they defend their rights, and tell the truth", "they prefer team sports", "they think that the sports enables social integration", "they express themselves more liberally in the sportive activities", "they think that the sportive activities contribute to the social integration", "they believe that the sports have positive contributions to the interpersonal communication", "they can easily adapt to any sportive activity", "they easily establish communication in the sportive activities", "they believe that the sports training has an important role in raising socially beneficial individuals", "they state that the sports can help to explore the personal abilities", "they believe that the sports will develop positive emotions towards the others", "they like to spend their free time with the others", "they like to do sports with their friends".

H1. a. 2. The following deductions could be made for the university students with structures relating to an external locus of control: "they do not tolerate the outlaw behaviors in the sportive activities", "they prefer to have their own value structures rather than being a part of a group", "their families and environments are determinant in the sports branch they are interested in".

Table 3. Results pertaining to the participants' socialization and locus of control structures.

Socialization scale, item no and item

1. I prefer to stay away from the crowds as much as possible

5. I like to participate in any sort of social activities

6. I prefer helping the other people instead of arguing in public

8. I hesitate to talk to the people I've met only recently

9. I usually feel lonely when in public

13. I forget about my grief and problems when I am in public with my beloved ones

17. Behaviors of those people acting against the social values are disturbing to me

23. My family has an active role in specifying my circle of friends

24. I'm troubled with people who try to judge or direct my behaviors

26. School plays an important role in developing respect for the social and personal values

27. I don't like discriminations against the age, gender, and beliefs etc. in attending the social activities

29. I like to meet new people, and get engaged in social activities

31. I prefer being respectful for the value perceptions in different cultures

32. Everyone should be able to liberally live their cultures and values, and express themselves

33. Different cultural perceptions is the key dynamics in the social peace
According to their internal locus of control characteristics

According to their external locus of control characteristics

$\mathrm{t}=3.712 ; \quad \mathrm{sd}=172 ;$ $\mathrm{x}=2.91 ; \mathrm{p}<.000$

$$
\begin{gathered}
\mathrm{t}=-3.419 ; \quad \mathrm{sd}=172 ; \\
\mathrm{x}=3.93 ; \mathrm{p}<.001 \\
\mathrm{t}=-2.332 ; \quad \mathrm{sd}=172 ; \\
\mathrm{x}=3.87 ; \mathrm{p}<.021
\end{gathered}
$$

$$
\begin{array}{cc}
t=5.122 ; & \mathrm{sd}=172 ; \\
\mathrm{x}=3.00 ; & \mathrm{p}<.000 \\
\mathrm{t}=3.692 ; & \mathrm{sd}=172 ; \\
\mathrm{x}=2.99 ; & \mathrm{p}<.000
\end{array}
$$

$\mathrm{t}=-2.577 ; \quad \mathrm{sd}=172$ $\mathrm{x}=4.08 ; \mathrm{p}<.011$

$$
\begin{array}{cc}
t=2.261 ; & s d=172 ; \\
x=3.61 ; & p<.025 \\
t=2.588 ; & s d=172 ; \\
x=2.89 ; & p<.010
\end{array}
$$

$\mathrm{t}=-3.632 ; \quad \mathrm{sd}=172$

$\mathrm{x}=4.11 ; \mathrm{p}<.000$

$\mathrm{t}=-2.448 ; \quad \mathrm{sd}=172$;

$\mathrm{x}=4.09 ; \mathrm{p}<.015$

$\mathrm{t}=-2.793 ; \quad \mathrm{sd}=172$;

$\mathrm{x}=4.14 ; \mathrm{p}<.006$

$\mathrm{t}=-2.677 ; \quad \mathrm{sd}=172$; $\mathrm{x}=4.05 ; \mathrm{p}<.008$

$\mathrm{t}=-2.404 ; \quad \mathrm{sd}=172$; $\mathrm{x}=4.08 ; \mathrm{p}<.017$

$\mathrm{t}=-3.388 ; \quad \mathrm{sd}=172$; $\mathrm{x}=4.20 ; \mathrm{p}<.001$

$\mathrm{t}=-2.818 ; \quad \mathrm{sd}=172$; $\mathrm{x}=4.05 ; \mathrm{p}<.005$

H1. b. 1. The following deductions could be made for the university students with structures relating to an internal locus of control: "they like to participate in any sort of social activities", "they prefer to help the other people instead of arguing with them", "they forget about their grief and problems when they are together with their beloved ones", "they feel uncomfortable when their behaviors are judged and directed", "they believe that the school plays an important role in 
developing respect towards the personal, social, and individual values", "they participate in the social activities with no exception", "they meet new people, and get engaged in social activities", "they are respectful towards the value perceptions in different cultures", "they think that everyone should be able to liberally live their cultures and values, and express themselves", "they think that the different cultural perceptions is the key dynamics in establishing the social peace".

H1. b. 2. The following deductions could be made for the university students with structures relating to an external locus of control: "they prefer to stay away from the crowds", "they hesitate to talk to the people they meet", "they usually feel lonely when in public", "they are disturbed by the behaviors of those who act against the social values", "their families play an active role in determination of their circle of friends".

\subsection{Hypothesis 2: What is the Relationship between the Socialization of the University Students and Their Interest in} Sports?

Regarding this hypothesis, we have analyzed the socialization of the university students as well as their interests in both individual and team sports, and reached a series of significant results. Interests in the individual and team sports have been classified as "professional", "amateur", "spectator", and "no interest". Among the results pertaining to the relation between the items included in the socialization scales and the interests in sports, the significant ones have been included here, whereas the others have been cleaned out.

Table 4. Results pertaining to the participants' socialization and interest in individual sports.

\begin{tabular}{|c|c|c|}
\hline \multirow{2}{*}{ Socialization scale, item no and item } & \multicolumn{2}{|c|}{ Interest in Individual Sports } \\
\hline & Amateur & Spectator \\
\hline 5. I like to participate in any sort of social activities & $\mathrm{p}<.047 ; \mathrm{x}=3.86$ & \\
\hline 6. I prefer helping the other people instead of arguing in public & & $\mathrm{p}<.002 ; \mathrm{x}=3.79$ \\
\hline 7. I'm skilled at leading the society in social matters & $\mathrm{p}<.009 ; \mathrm{x}=3.66$ & \\
\hline 10. I easily communicate with the other members of the society & $\mathrm{p}<.008 ; \mathrm{x}=3.92$ & \\
\hline 29. I like to meet new people, and get engaged in social activities & $\mathrm{p}<.022 ; \mathrm{x}=4.06$ & \\
\hline 31. I prefer being respectful for the value perceptions in different cultures & $\mathrm{p}<.000 ; \mathrm{x}=4.19$ & \\
\hline $\begin{array}{l}\text { 32. Everyone should be able to liberally live their cultures and values, and } \\
\text { express themselves }\end{array}$ & $\mathrm{p}<.007 ; \mathrm{x}=4.18$ & \\
\hline 33. Different cultural perceptions is the key dynamics in the social peace & $\mathrm{p}<.008 ; \mathrm{x}=4.33$ & \\
\hline
\end{tabular}

H2. a. 1. The following deductions could be made for the university students who have "amateur" interests in individual sports: "they like to participate in social activities", "they are skilled at leading the society in social matters", "they can easily communicate with others", "they like to get engaged in social activities", "they prefer to be respectful for the value perceptions in different cultures", "they think that everyone should be able to liberally live their cultures and values, and express themselves", "they think that the different cultural perceptions is the key dynamics in establishing the social peace".

H2. a. 2. The following deduction could be made for the university students who have "spectator" interests in individual sports: "they prefer helping the other people instead of arguing in public".

No significant differences have been encountered between the socialization items and the interests in individual sports among the "professional" and "no interest" groups.

Table 5. Results pertaining to the participants' socialization and interest in team sports.

\begin{tabular}{|c|c|c|c|}
\hline \multirow{2}{*}{ Socialization scale, item no and item } & \multicolumn{3}{|c|}{ Interest in Team Sports } \\
\hline & Amateur & Professional & No Interest \\
\hline 3. People can easily establish communication with me in public & $\mathrm{p}<.015 ; \mathrm{x}=3.81$ & & \\
\hline 4. I generally lead the society in social matters & & $\mathrm{p}<.000 ; \mathrm{x}=3.56$ & \\
\hline 5. I like to participate in any sort of social activities & $\mathrm{p}<.000 ; \mathrm{x}=3.88$ & & \\
\hline 6. I prefer helping the other people instead of arguing in public & $\mathrm{p}<.000 ; \mathrm{x}=4.00$ & & \\
\hline 9. I usually feel lonely when in public & & & $\mathrm{p}<.015 ; \mathrm{x}=3.46$ \\
\hline $\begin{array}{l}\text { 19. I contribute to the process of making decisions about the } \\
\text { family }\end{array}$ & $\mathrm{p}<.035 ; \mathrm{x}=3.90$ & & \\
\hline $\begin{array}{l}\text { 31. I prefer being respectful for the value perceptions in different } \\
\text { cultures }\end{array}$ & $\mathrm{p}<.042 ; \mathrm{x}=4.13$ & & \\
\hline $\begin{array}{l}\text { The value which differentiates us from the other cultures is to } \\
\text { belong to different cultures in peace and harmony }\end{array}$ & $\mathrm{p}<.008 ; \mathrm{x}=4.01$ & & \\
\hline
\end{tabular}


H2. b. 1. The following deductions could be made for the university students who have "amateur" interests in team sports: "they can easily get into communication with the others", "they like to participate in social activities", "they prefer helping the other people instead of arguing in public", "they contribute to the process of making decision about the family", "they think that different cultures exist in peace and harmony".

H2. b. 2. The following deduction could be made for the university students who have "professional" interests in team sports: "they generally lead the society in social matters".

H2. b. 3. Students in the "no interest" group regarding the team sports "generally feel lonely when in public".

No significant differences have been encountered between the students' socialization and their interests in individual sports among the "no interest" group.

Table 6. Results pertaining to the findings about the participants' socialization in sports and their interests in team sports.

Sports and socialization scale, item no and item

Interest in Team Sports

Amateur No Interest

1. My personal interests and skills are determinant in selecting the sports branch that I'm interested

$\mathrm{p}<.005 ; \mathrm{x}=4.08$

4. I like to do sports with individuals of any age group, gender, and income level

$\mathrm{p}<.018 ; \mathrm{x}=3.95$

17. Even though the others might disaffirm me, I defend my rights and tell the truth

$\mathrm{p}<.049 ; \mathrm{x}=3.96$

23. I prefer having an original value structure rather than being part of a group

$\mathrm{p}<.048 ; \mathrm{x}=3.62$

24. Sports have positive contributions to the interpersonal communication

$\mathrm{p}<.017 ; \mathrm{x}=4.08$

H2. c. 1. The following deductions could be made for the university students who have "amateur" interests in team sports: "their personal interests and skills are determinant in selecting the sports branch they are interested in", "they like to do sports with individuals of any age, gender, and income level", "they defend their rights, and tell the truth", "they believe that the sports have positive contributions to the interpersonal communication".

H2. c. 2. The following deduction could be made for the university students who have "no interest" in team sports: "they prefer having their own original value structures rather than being part of a group".

Among the students in the "professional" and "spectator" groups, no significant differences have been found between the students' socialization in sports and their interests in team sports.

Table 7. Results pertaining to the findings about the participants' socialization in sports and their interests in individual sports.

Sports and socialization scale, item no and item

Interest in Individual Sports

Amateur

1. My personal interests and skills are determinant in selecting the sports branch that I'm interested

$\mathrm{p}<.001 ; \mathrm{x}=4.08$

24. Sports have positive contributions to the interpersonal communication $\quad \mathrm{p}<.000 ; \mathrm{x}=4.08$

The following deductions could be made for the university students who have "amateur" interests in individual sports: "their personal interests and skills are determinant in selecting the sports branch they are interested in", "they believe that the sports have positive contributions to the interpersonal communication".

No significant differences have been found between the other students of the "professional", "no interest", and "spectator" groups, and the interest in individual sports.

3.3 Hypothesis 3: What is the relationship between socialization and the gender of the university students?

Findings related to the Hypothesis 3 are presented in Table 8. 
Table 8. Results pertaining to the findings about the participants' socialization and their genders.

\begin{tabular}{|c|c|}
\hline \multirow{2}{*}{ Sports and socialization scale, item no and item } & Gender \\
\hline & Female \\
\hline $\begin{array}{l}\text { 10. I do not like to keep my emotions under control during the sportive } \\
\text { activities }\end{array}$ & $\begin{array}{l}.1 ; \mathrm{sd}=172 \\
\mathrm{x}=3.42 ; \mathrm{p}<.005\end{array}$ \\
\hline $\begin{array}{l}\text { 22. Could the outlaw behaviors in the sportive activities be tolerated (cursing, } \\
\text { actions contradicting the gentlemanship) }\end{array}$ & $\begin{array}{l}.05 ; \mathrm{sd}=172 \\
\mathrm{x}=2.93 ; \mathrm{p}<.005\end{array}$ \\
\hline 23. I prefer having an original value structure rather than being part of a group & $\begin{array}{l}.98 ; \mathrm{sd}=172 \\
\mathrm{x}=3.45 ; \mathrm{p}<.005\end{array}$ \\
\hline 32. I like to do sports with my friends & $\begin{array}{l}.05 ; \mathrm{sd}=172 \\
\mathrm{x}=4.18 ; \mathrm{p}<.005\end{array}$ \\
\hline
\end{tabular}

Of all the university students participating in the research, no differences have been found regarding the items in the socialization scale. However, a number of differences between the sports and socialization scale and the genders have been observed regarding some items in the scale, and these differences are for the benefit of the female students. Only the results representing significant differences have been included here, and the others have been cleaned out. Accordingly, the following deductions could be made regarding the female university students when their socialization in sports is analyzed: "they do not like to keep their emotions under control during the sportive activities", "they do not tolerate the outlaw behaviors in the sportive activities", "they prefer having their own original value structures rather than being part of a group", "they like to do sports with their friends". When all these data are taken into consideration, the male university students are observed to be more positive in both the general socialization skills and the socialization skills in sports.

\section{Discussion}

There were significant differences between internal and external locus of control of the participants and their general socialization skills. University students' socialization skills in sports mostly varied in internal locus of control. While fewer items were related to their external locus of control, this might be interpreted as a positive predictor for university students' socialization skills in sports. A similar result was reached in general socialization skills of university students. These results are in line with the researches of Biddle and Mutrie (2008), Steptoe and Wardle (2001), Pearson's and Betz (2001), and McCready and Long (1985). Saone and De Carole (2014) specify that university students who believe that they have control of their own lives have internal locus of control. Gün (2006) also indicated that those who do sports have higher self-respect.

Results revealed significant differences between university students' interest both in individual sports and team sports, and general socialization skills and the socialization skills specific to sports. More significant differences were found in the socialization skills of university students who have "amateur" interests in individual sports than in other groups. University students who have "amateur" interests in team sports have more socialization skills than other groups. In terms of socialization skills in sports, significant differences were mostly identified in university students who have "amateur" interests in both individual and team sports.

There were no significant differences between socialization skills and genders. However, a number of differences between the sports and socialization scale and the genders were determined. In regard to some items in the scale, female university students have more socialization skills than male students. Research by Drake et al. (2014), Aydan Koru cu (2010), Ozcelik (2007), Parsons and Betz, (2001), and Giuliano et al., (2000) supports the findings of this study.

According to the findings of this study, modifications need to be done in order to provide university students extensive and regular sport programs. Thus, sport activities are offered in a wide range, considering gender equity. Recommendations should be evaluated within the study's limitations, including the sampling strategy and the limited sample size.

\section{References}

Abusabha, R., \& Achterberg, C. (1997). Review of Self Efficacy and Locus of Control for Nutrition and Health-Related Behavior. Journal of the American Dietetic Association, 97(10), 1122-1132. http://dx.doi.org/10.1016/S0002-8223(97)00273-3

Artinger, L., \& Forrester, S. A. (2006). The Social Benefits of Intramural Sports. NASPA Journal, 43(1), 69-86. http://dx.doi.org/10.2202/0027-6014.1572 
Aytan, K. G. (2010). Ortaöğretim Ŏgrencilerinin Sosyalleşmelerinde Sporun Etkisi. (Unpublished doctorate dissertation). Gazi University, Ankara, Turkey.

Barbalet, J. M. (2004). Emotion, Social Theory And Social Structure: A macrosociological approach. Cambridge: Cambridge University Press.

Bilgin, A. (2010). Üniversite öğrencilerinin çeşitli değiş̧kenlere ve denetim odağına göre problem çözme beceri algıları. (Unpublished master thesis). Marmara University, İstanbul, Turkey.

Çakıcı, D. (2010). Spor Lisesi Ve Genel Lise 9. Ve 10. Sinıf Öğrencilerinin Sosyal Etkinlik Beklentisi Ve Özsaygl DÜZeylerinin Incelenmesi. (Unpublished Master Thesis). Mersin University, Mersin, Turkey.

Çırakoğlu, O. C., \& Tezer, E. (2010). Kontrol odağı ve eleştirel düşünmenin üniversite öğrencilerinin ilişki doyumsuzluklarına verdikleri tepkiler üzerindeki yordayıc1 rolü. Türk Psikoloji Yazılarl, 13(26), 29-41

Dağ, İ. (2002). Kontrol odağı ölçeği (KOÖ): Ölçek geliştirme, güvenirlik ve geçerlik çalışması. Türk Psikoloji Dergisi, 17(49), 77-90.

Davis, B. S., \& Menard, S. (2013). Long Term Impact of Youth Sports Participation on Illegal Behavior. The Social Science Journal, 50(1), 34-44. http://dx.doi.org/10.1016/j.soscij.2012.09.010

Dinger, M. K., Behrens, T. K., \& Han, J. L. (2006). Validity and Reliability of the International Physical Activity Questionnaire in College Students. American Journal of Health Education, 37(6), 337-343. http://dx.doi.org/10.1080/19325037.2006.10598924

Drake, K. M., Longacre, M. R., MacKenzie, T., Titus, L. J., Beach, M. L., Rundle, A. G., \& Dalton, M. A. (2014). High School Sports Programs Differentially Impact Participation by Sex. Journal of Sport and Health Science, 1-7. http://dx.doi.org/10.1016/j.jshs.2013.11.006

Giuliano, T., Popp, K., \& Knight, J. (2000). Footballs versus barbies: Childhood Play Activities as Predictors of Sport Participation by Women. Sex Roles, 42(3/4), 159-181. http://dx.doi.org/10.1023/A:1007035122089

Gün, E. (2006). Spor yapanlarda ve spor yapmayan ergenlerde benlik saygısı. Unpublished Master Thesis. Cukurova University. Adana.

Grusec, J. E., \& Hastings, P. D. (2007). Introduction. Grusec, J. E., Hastings, P.D. (Edt). Handbook of socialization: Theory and research. (1-9). New York, NY: The Guilford Press.

Howkins, E. J., \& Evens, A. (1999). How Students Experience Professional Socialization. International Journal of Nursing Studies, 35, 41-49. http://dx.doi.org/10.1016/S0020-7489(98)00055-8

Hussain, S. (2012). Socialization Through Sports. Indian Streams Research Journal, 2, 1-3.

Jewett, R., Sabiston, C. M., Brunet, J., O’Loughlin, E. K., Scarapicchia, T., \& O’Loughlin, J. (2014). School Sport Participation during Adolescence and Mental Health in Early Adulthood. The Journal of Adolescent Health: Official Publication of the Society for Adolescent Medicine, 55(5), 640-644. http://dx.doi.org/10.1016/j.jadohealth.2014.04.018

Karasar, N. (2006). Araştırmalarda Rapor Hazırlama. Ankara: Nobel Yayın Dağıtım.

Keshavarz, S. \& Baharudin, R. (2012). The Moderating Role of Gender on the Relationships between Perceived Parenting Style, Locus Of Control And Self-Efficacy. Procedia-Social and Behavioral Sciences, 32, 63-38. http://dx.doi.org/10.1016/j.sbspro.2012.01.011

Kilpatrick, M., Hebert, E., \& Bartholomew, J. (2005). College Student's Motivation for Physical Activity: Differentiating Men's and Women's Motives for Sport Participation and Exercise. Journal of American College Health, 54(2), 68-94. http://dx.doi.org/10.3200/JACH.54.2.87-94

Kimball, A., \& Freysinger, V. (2003). Leisure, stress, and coping: The Sport Participation of Collegiate Student-Athletes. Leisure Sciences, 25, 115-141. http://dx.doi.org/10.1080/01490400306569

Kiremitçi, O. (2007). Illköğretim ikinci kademe ögrencilerinin spor yapma durumlarına göre sosyalleşme seviyeleri. (Unpublished master thesis). Ege Universitesi, Izmir, Turkey.

Koivula, N. (1999). Sport participation: Differences in Motivation and Actual Participation Due to Gender Typing. Journal of Sport Behavior, 22(2), 360-380.

Küçükkaragöz, H., Akay, Y., \& Canbulat. T. (2013). Rotter iç- dış kontrol odağı ölçeğinin öğretmen adaylarında geçerlik ve güvenirlik çalışması, Akademik Bakış Dergisi, 35, 1-12.

Krustrup, P., Helsen, W., Randers, M. B., Christensen, J. F., MacDonald, C., Rebelo, A. N., \& Bangsbo, J. (2009). 
Activity Profile and Physical Demands of Football Referees and Assistant Referees in International Games. Journal of Sports Sciences, 27(11), 1167-76. http://dx.doi.org/10.1080/02640410903220310

Maccoby, E. E. (2007). Historical Overview of Socialization Research and Theory. Grusec, J. E., Hastings, P. D. (Edt). Handbook of socialization: Theory and research. (13-41). New York, NY: The Guilford Press.

Marsh, H. W. (1993). The Effects of Participation in Sport during the Last Two Years of High School. Sociology of Sport Journal, 10, 18-43.

McCready, M., \& Long, B. (1985). Locus of control, attitudes toward physical activity, and exercise adherence. Journal of Sport Psychology, 7, 346-359. $\quad$ Retrieved from http://scholar.google.com/scholar?hl=en\&btnG=Search\&q=intitle:Locus+of+Control+,+Attitudes+Toward+Physic al+Activity+,+and+Exercise+Adherence\#0_

Mueller, S., \& Thomas, A. S. (2000). Culture and Entrepreneurial Potential: A Nine Country Study of Locus of Control and Innovativeness. Journal of Business Venturing, 16, 51-75. http://dx.doi.org/10.1016/S0883-9026(99)00039-7

Parsons, E. M., \& Betz, N. E. (2001). The Relationship of Participation in Sports and Physical Activity to Body Objectification, Instrumentality, and Locus of Control among Young Women. Psychology of Women Quarterly, 25(3), 209-222. http://dx.doi.org/10.1111/1471-6402.00022

Pot, N., Schenk, N., \& van Hilvoorde, I. (2014). School Sports and Identity Formation: Socialisation or Selection? European Journal of Sport Science, 14(5), 484-91. http://dx.doi.org/10.1080/17461391.2013.873483

Rees, D. I., \& Sabia, J. J. (2010). Sports Participation and Academic Performance: Evidence from the National Longitudinal Study of Adolescent Health. Economics of Education Review, 29(5), 751-759. http://dx.doi.org/10.1016/j.econedurev.2010.04.008

Seefeldt, V. D., \& Ewing, M. E. (1997). Youth Sports In America: An Overview. President's Council on Physical Fitness and Sports Research Digest (ERIC), 2(11), 3-14. Retrieved from http://eric.ed.gov/?id=ED413324

Steptoe, A., \& Wardle, J. (2001). Locus of Control and Health Behavior. British Journal of Psychology, 92, 659-672. http://dx.doi.org/10.1348/000712601162400

Strong, W. B., Malina, R. M., Blimkie, J. R., Daniels, S. R., Dishman, R. K., \& Gutin, B. (2005). Evidence Based Physical Activity For School-Age Youth. J. Pediatr, 146, 732-737. http://dx.doi.org/10.1016/j.jpeds.2005.01.055

Telama, R., Yang, X., Hirvensalo, M., \& Raitakari, O. (2006). Participation in Organized Youth Sport as A Predictor of Adult Physical Activity : A 21-Year Longitudinal Study. Pediatric Exercise Science, 17, 76-88.

Vilhjalmsson, R., \& Kristjansdottir, G. (2003). Gender Differences in Physical Activity in Older Children and Adolescents: The Central Role of Organized Sport. Social Science \& Medicine, 56(2), 363-374. http://dx.doi.org/10.1016/S0277-9536(02)00042-4

Weiss, G. L., \& Larsen, D. L. (1990). Health Value, Health Locus of Control, and the Prediction of Health Protective Behaviors. Social Behavior and Personality: An International Journal, 18(1), 121-136. http://dx.doi.org/10.2224/sbp.1990.18.1.121 